\title{
МЕДІАКУЛЬТУРА
}

Visn. Lviv. Univ., Ser. Zhurn. 2020: 48; 127-133 • DOI: http://dx.doi.org/10.30970/vjo.2020.48.10552

УДК 316.776.23:070.41:004.738.5-028.71]:271.2(477)

\section{РЕЛІГІЙНА ПРОБЛЕМАТИКА В МАТЕРІАЛАХ ІНТЕРНЕТ-МЕДІА ЛЬВІВЩИНИ: КОНЦЕПТУАЛЬНО-ЗМІСТОВА СКЛАДОВА}

\author{
Оксана Гоцур \\ Львівський національний університет імені Івана Франка \\ вул. Генерала Чупринки, 49, 79044, Львів, Украӥна \\ e-mail: o hotsur@ukr.net \\ https://orcid.org/0000-0002-6589-0011
}

У статті проаналізовано матеріали на релігійну проблематику інтернет-медіа Львівщини. На основі контент-аналізу текстів таких відомих регіональних онлайнових видань, як «ZIK», «Zaxid.NET», «Дивись.Info», виокремлено концептуальні акценти у висвітленні релігійних питань. Також розкрито негативне змістово-смислове навантаження матеріалів на релігійну проблематику.

3'ясовано, що вагому частку текстів на релігійну проблематику становлять матеріали, які текстуально та концептуально протиставляють Українську Православну Церкву Московського Патріархату та Православну Церкву України.

Ключові слова: журналістські матеріали, концепт, публікація, релігійна проблематика, інтернет-медіа, ПЦУ, УПЦ МП.

Актуальність дослідження. Інтернет-медіа порівняно із традиційними медіа мають більші і ширші можливості не тільки в плані швидкого інформування, оперативності, інтерактивності, мультимедійності, гіпертекстуальності, а й у впливі на громадську думку. Можливості у процесі їі формування є надзвичайно потужними. Тому концептуально-змістове навантаження журналістських текстів інтернет-медій $\epsilon$ важливим, адже зумовлює парадигму бачення і розуміння у суспільстві питань, які становлять контекст його буття.

3 позицій змістово-смислових потрібно звернути увагу на мову ворожнечі, яку журналісти, відповідно до висновків науковців, особливо активно використовують 3 початком російсько-української війни 2014 року. Саме ці події, на думку дослідників медіа, стали причиною функціонування мови ворожнечі у журналістських матеріалах, у яких розкривалися проблеми війни на сході України, тимчасово переміщених осіб з окупованих територій тощо.

Щодо визначення поняття «мова ворожнечі», то потрібно зважати на такий момент: цей термін є запозичений і використовується на позначення hate speech. Іншим

(C) Гоцур О., 2020 
його перекладом є «мова ненависті». Рекомендації Комітету міністрів Ради Європи R (97) 20, ухвалені 30 жовтня 1997 року, подають визначення hate speech. I це визначення $€$ найбільш відомим у наукових колах: мова ворожнечі, мова ненависті - усі форми вираження, котрі поширюють, розпалюють, підтримують або впорядковують расову ненависть, ксенофобію, антисемітизм чи інші форми ненависті, що базуються на нетерпимості ${ }^{1}$. Мова ворожнечі грунтується на таких явищах, як соціальні стереотипи, упередження, дискримінація.

Українське законодавство також подає формулювання мови ворожнечі. Маємо на увазі Закон України «Про інформацію» ( Ст. 5), Закон України «Про друковані засоби масової інформації (пресу) в Україні» (Ст. 3, 4), Закон України «Про телебачення і радіомовлення» (Ст. 6). Таким чином, правове поле визначає одну з ознак мови ворожнечі - заклики до розпалювання міжетнічної, расової та релігійної ворожнечі.

Аналіз останніх досліджень та публікацій. Велика кількість ознак мови ворожнечі постали внаслідок реакції на специфічні соціальні і суспільні явища та інциденти. Українські науковці зовсім недавно зацікавились проблемою hate speech y 3MI. Власне, варто наголосити, що саме соціальні комунікації є благодатним грунтом не лише для її створення і поширення, а й пропагування.

Досліджуючи мову ворожнечі в медіа, І. Каляпух акцентує увагу на тому, що явище hate speech $є$ одним із гібридних методів ведення сучасних воєн в інформаційному просторі. ${ }^{2}$

Використання мови ворожнечі в мережі інтернет розглядає російський дослідник А. Верхівський. ${ }^{3}$

Феномен мови ворожнечі, на думку А. Глушко, є складовою комплексної проблеми, у рамках якої сьогодні тривають дискусії щодо норм і меж застосування тих чи інших інструментів як інформаційної зброї та етичних вимог щодо висвітлення проблем. ${ }^{4}$

Здебільшого українські науковці досліджували наявність мови ворожнечі у матеріалах на військову проблематику. У цьому контексті цікавими є праці А. Глушко, Т. Ісакової 6 , Р. Пикалюк ${ }^{7}$, К. Темчур ${ }^{8}$. Власне К. Темчур зауважує, що мову ворожнечі щодо висвітлення російської воєнної агресії постійно поширюють одні й ті самі ме-

\footnotetext{
1 Законодавство України (1997), Рекомендація № R(97) 20 Комітету міністрів Ради Свропи краӥнам-учасникам щьодо питання "розпалювання ненависті», 30 жовтня 1997, доступно за адресою: https://zakon.rada.gov.ua/laws/show/994_093 (дата перегляду 30 жовтня 2019).

2 Каляпух, І. (2017), «Мова ворожнечі» в засобах масової інформації», Діалог: Медіа-студіï, № 24, c. $132-154$.

3 Верховский, А., ред. (2007), Язык вражды против общества: (сб. статей), Москва, 259 с.

4 Глушко, А. (2017), «Візуальні засоби мови ворожнечі як інструмент інформаційної війни», Діалог: медіа-студї̈, № 23, с. 132-155.

5 Там само.

6 Ісакова, Т. (2016), «Мова ворожнечі як проблема українського інформаційного простору», Стратегічні пріоритети: Серія Політика, № 4, с. 90-97.

7 Пикалюк, Р. (2018), «Мова ворожнечі та вдосконалення стандарті вітчизняної медіа діяльності. Права людини та мас-медіа в Україні», Збірник конспектів лекцій, ред. I. Виртосу, С. Шендеровського, Інститут журналістики, КНУ ім. Т. Шевченка, Київ, с. 135-147.

8 Темчур, К. (2019), «Конфліктний дискурс українських медіа під час агресії Росії в Азовському морі», Вісник Харківської державної академії культури, № 54, с. 108-116.
} 
діа. Це, на їі думку, є наслідком відсутності в Україні законодавчого регулювання висвітлення російсько-українського конфлікту та саморегулювання медіа.

Що ж стосується hate speech в журналістських матеріалах на релігійну проблематику, то таких досліджень $є$ одиниці. Зокрема, заслуговує нашої уваги праця В. Савончака «Мова ворожнечі у 3МI: до дискусії про поняття», у якій він наголошує: «Такими словами, як «уніяти», «сектанти», «націоналісти», «розкольники», «іновірці», «атеїсти» тощо автори мимоволі показують ставлення до релігійних подій та міжконфесійних відносин, забуваючи про елементарні правила журналістської етики». Відповідно до його визначення, «мова ворожнечі - це спосіб мовного конструювання моделей і практик соціальної нерівності»?

Важливим дослідженням щодо нашої проблеми є збірник конспектів лекцій «Права людини та мас-медіа в Україні» ${ }^{10}$, який розглядає не тільки права людини та медіядільність, етичні засади сучасної журналістики, а й мову ворожнечі у розділі «Слово проти дискримінації».

Джерельна база дослідження. Основу нашого дослідження становлять журналістські матеріали на релігійну проблематику інтернет-медіа Львівщини, а саме «ZIKy», «ZAXID.NETy» та «Дивись.INFO».

Вибір для аналізу цих ресурсів зумовлюють декілька чинників. По-перше, інтернет-медіа займають вагому частку інформаційного простору України. По-друге, ці онлайн-видання мають щодня велику кількість відвідувачів, що, відповідно, свідчить про авторитетність і вплив на громадську думку. По-третє, часто авторами публікацій є відомі науковці, літератори та громадські діячі, що є критеріями іміджевості інтернет-медій, показниками для рейтингів.

Хронологічні рамки дослідження. Період дослідження охоплює 2013-2019 pp., що пов'язане із суспільно-політичними та релігійними зрушеннями і трансформаціями в житті України.

Методи дослідження. Соціальнокомунікаційний та аксіологічний підходи, методи контент-аналізу, синтезу та узагальнення є основними методами, які були використані у процесі наукового дослідження.

Основний виклад матеріалу. Перш ніж перейти до аналізу журналістських текстів на релігійну проблематику, потрібно поставити питання: чому мова ворожнечі як складова концептуально-змістового навантаження публікацій активно функціонує у ЗМІ? Член Комісії із журналістської етики Тетяна Печончик визначає три причини:

1) журналісти хочуть посилити цікавість до своєї новини і для цього спеціально вдаються до маніпуляцій;

2) недостатній рівень знань та відсутність толерантності;

3) спеціальне використання мови ворожнечі, як це роблять російські ЗМІ під час російсько-української війни ${ }^{11}$.

\footnotetext{
9 Савончак, В. (2018), «Мова ворожнечі у ЗМІ: до дискусії про поняття», Вісник Харківського національного університету імені В. Н. Каразіна. Серія «Філологія», № 79, с. 76-81.

${ }^{10}$ Виртосу, А., Шендеровський, С., ред. (2018), Права людини та мас-медіа в Украӥні: Збірник конспектів лекиій, Інститут журналістики КНУ ім. Т. Шевченка, Київ, 260 с.

${ }^{11}$ Печончик, Т. (2016), «Чому мова ворожнечі з’являється у ЗМІ», Комісія з журналістської етики, Доступно на URL: http://www.cje.org.ua/ua/blog/chomu-mova-vorozhnechi-zyavlyayetsya-u-zmi (дата звернення 3.11.2019).
} 
Суспільно-політичні процеси, які відбувалися у державі упродовж 2013-2019 pp., стали каталізаторами висвітлення релігійної проблематики у медіа. Зокрема, з погляду хронології насамперед потрібно говорити про воєнні події на сході України та набуття Православною Церквою України автокефалії, що підтверджено томосом.

Російсько-українська війна позначилась не тільки на суспільно-політичних, економічних, культурних, гуманітарних концептах буття народу, держави. Вона також стала каталізатором нового розуміння актуальності церковного життя, його ролі у побудові країни. Насамперед це пов'язано із поліконфесійністю, існуванням трьох гілок православних церков УПЦ МП, УПЦ КП, УАПЦ.

Негативне сприйняття УПЦ МП в українському суспільстві під час воєнних дій на сході України зумовлене тим, що діяльність Московського патріархату на теритоpiї держави була спрямована не дише на духовну, а й на політичну сферу.

У цьому контексті заслуговує на увагу стаття інформаційної агенції «ZAXID. NET» «Путіністи в рясах. На краю «церковного» вулкану» (15.12.2015), опублікована у рубриці «IQ». У матеріалі читаємо про причини переходу вірян з УПЦ МП, УПЦ КП та про реальну діяльність очільників УПЦ МП на території України. Окрім того, автор намагається окреслити можливі шляхи зменшення парафій, а значить і впливу цієї Церкви, розуміючи усю дражливість самого питання для думки суспільства. Але не тільки у заголовку, а у самому тексті присутне гостро негативне навантаження тексту через такі концепти, як одіозний nin, «кадебешники» у рясах, «міль» РПЦ, «nатріарх» Кіріл, попи з погонами під рясами, путінська ичерковна «ядерна зброя».

Фактично вищенаведений матеріал інтернет-видання за смисловим навантаженням генерує парадигму кримінальності УПЦ МП і створює негативний образ цієї релігійної групи. До речі, ці позиції частково висвітленні у класифікаторі мови ворожнечі в українських ЗМІ, яку розробив інформаційно-аналітичний центр «Сова» ${ }^{12}$.

У ракурсі негативного змістово-концептуального смислу написана ще одна публікація інтернет-видання «ZAXID.NET», а саме: «Релігійна війна. Патріарх Кіріл підклав свиню Київькому митрополитові» (15.08.2014). Зокрема, тут читаємо: «Тепер фактично провівши інформаційне вкидання, негідник $і$ корисливий очолює РПЦ хоче спровокувати внутрікофесійний конфлікт, який може тільки ще більше розколоти суспільство в Україні. Цей мерзотник, щуо живе не за законами Божими, а за вказівкою Путлера, фактично підштовхує людей до першої релігійної війни ХХІ століття в Свропі».

Отримання Православною Церквою України автокефалії і томосу аналізували чи не усі українські медіа. Власне, цю тему найчастіше розглядали у ключі протистояння новоутвореної церковної структури з Російською православною церквою, яка діє через Українську Православну Церкву Московського Патріархату. Саме про це читаємо у матеріалі вищезазначеного інтернет-ресурсу «Темний бік томосу. На які жертви пішла УПЦ КП заради автокефалї̈ (15.01.2019). Уже у першій частині матеріалу, де автор обговорює поняття канонічності церкви, натрапляємо на ворожі у смисловому плані концепти, а саме: «...тисячі нерішучих московських вірян отримали остаточний доказ «легітимності» украӥнської ичеркви» (йдеться про вірян УПЦ МП), «...московські священики залякували украӥнських вірян...».

12 Печончик, Т. (2016), «Чому мова ворожнечі з’являється у 3МI»... Доступно на URL: http://www. cje.org.ua/ua/blog/chomu-mova-vorozhnechi-zyavlyayetsya-u-zmi (дата звернення 3.11.2019). 
Власне, протиставлення, здійснене за принципом «свій - чужий», «московські віряни - українські віряни» зовсім не сприяють толерантному ставленню до людей різних конфесій та віросповідань. Це с свого роду твердженням про моральні недоліки тієї чи іншої релігійної групи.

Ще один приклад негативного розуміння та сприйняття релігійної атмосфери українського суспільства дає «ZIK» у новині «Російські попи ведуть масштабне будівництво на території Києво-Печерської лаври» (25.12.2018).

Окрім концепту «російські попи», трапляється у публікаціях і «кремлівські попи»: «У світлі автокефалї Украӥнської православної ичеркви кремлівські попи уже біжать з награбованим». (Міністерство культури терміново перевіряє Києво-Печерську лавру // ZIK, 29.11.2018).

Головна ідея статті «Яка конфесія патріотичніша. Про «релігійні війни» за нерухомість та владу» (ZAXID.NET, 11.03.2019) полягає у аналізі поглядів усіх трьох найбільших Церков на єдність Православної церкви України. Така постановка проблеми здійснена з позицій конфлікту та твердження про негативний вплив різних релігійних груп (конфесій) на суспільство та державу.

3 позицій складових мови ворожнечі написано аналітичний текст «ZIKy» «Життя після томосу» (20.12.2018). Тут вжито такі концепти, як загін промосковських попів, промосковські спископи, уніяти, канонічні, розкольники, розпіарене московське православ'я: «Нині ніхто не сумнівається: томос - буде! Гундяєв $з$ Путіним захлинуться власними слинами, але хід історії не змінять. А от щз далі? Як поведе себе передовий ударний путінський загін промосковських попів, куди дрейфуватимуть сотні парафій московського патріархату?»

Знову ж таки, основна мета статті - наголосити на потребі єдності у контексті творення Православної церкви України, але методи і шляхи висловлювань бачення тієї єдності у деяких подібних матеріалах регіональних інтернет-медій покликані зовсім навпаки - створити негативний образ релігійних організацій та їхніх вірян (особливий акцент на УПЦ МП) в українському суспільстві.

«Дивись.INFO», аналізуючи зустріч глави УГКЦ Блаженнішого Святослава 3 папою Римським, вживає концепт «уніат»: «I загалом мають рацію: воююча краӥна потребує духовного єднання через єдину Украйнську Церкву, яку, у випадку незалежності православних, можуть дати уніати» (Глава УГКЦ Святослав прагне патріархату. Чи зустріч з папою римським виправдала його очікування? - 18.07.2019).

Використання мови ворожнечі у матеріалах інтернет-медіа на релігійну проблематику становлять перспективу для подальших наукових досліджень.

Висновки.

Інтернет-медіа Львівщини реагують на релігійні події, зважаючи на загальноукраїнські суспільно-політичні процеси. Вороже та гостро негативне концептуально-змістове навантаження текстів притаманне матеріалам інтернет-видань на релігійну проблематику. 3 позицій смислових можна говорити про деякі ознаки мови ворожнечі у публікаціях на релігійну проблематику.

\section{СПИСОК ЛІТЕРАТУРИ}

1. Верховский, А., ред. (2007), Язык вражды против общества: (сб. статей), Москва, 259 с. 
2. Виртосу, А., Шендеровський, С., ред. (2018), Права людини та мас-медіа в Україні: Збірник конспектів лекцій, Інститут журналістики КНУ ім. Т. Шевченка, Київ, $260 \mathrm{c}$.

3. Глушко, А. (2017), «Візуальні засоби мови ворожнечі як інструмент інформаційної війни», Діалог: медіа-студіï, № 23, с. 132-155.

4. Законодавство України (1997), Рекомендаиія № R(97) 20 Комітету міністрів Ради Свропи країнам-учасникам щодо питання «розпалювання ненависті», 30 жовтня 1997, доступно за адресою: https://zakon.rada.gov.ua/laws/show/994_093 (дата перегляду 30 жовтня 2019).

5. Ісакова, Т. (2016), «Мова ворожнечі як проблема українського інформаційного простору», Стратегічні пріоритети: Серія Політика, № 4, с. 90-97.

6. Каляпух, I. (2017), «Мова ворожнечі» в засобах масової інформації», Діалог: $М$ dia-cmydiï, № 24, c. 132-154.

7. Печончик, Т. (2016), «Чому мова ворожнечі з’являється у ЗМІ», Комісія з журналістської етики, Доступно на URL: http://www.cje.org.ua/ua/blog/chomu-movavorozhnechi-zyavlyayetsya-u-zmi (дата звернення 3.11.2019).

8. Пикалюк, Р. (2018), «Мова ворожнечі та вдосконалення стандартів вітчизняної медіа діяльності. Права людини та мас-медіа в Україні», Збірник конспектів лекцій, ред. I. Виртосу, С. Шендеровського, Інститут журналістики, КНУ ім. Т. Шевченка, Київ, с. 135-147.

9. Савончак, В. (2018), «Мова ворожнечі у ЗМІ: до дискусії про поняття», Вісник Харківського нащіонального університету імені В. Н. Каразіна. Серія "Філологія», № 79, c. 76-81.

10. Темчур, К. (2019), «Конфліктний дискурс українських медіа під час агресії Росії в Азовському морі», Вісник Харківської державної академії культури, № 54, c. $108-116$.

\section{REFERENCES}

1. Legislation of Ukraine (1997), Recommendation No. R (97) 20 of the Committee of Ministers of the Council of Europe Committee of States Parties on the issue of "hate speech", 30 October 1997, available at: https://zakon.rada.gov.ua/laws/show/994 093 (revision date 30 October 2019).

2. Verkhovskyy, A. (Ed.) (2007), Hate speech against society: (collection of articles), Moscow, $259 \mathrm{p}$.

3. Glushko, A. (2017), "Visually pick up your mobile phone as a tool for information technology", Dialogue: media studio, no. 23, pp. 132-155.

4. Isakova, T. (2016), "What is the problem of the Ukrainian information space", Strategic Priorities: Seriya Politika, no. 4, pp. 90-97.

5. Kalyapukh, I. (2017), «The language of enmity» in mass media, Dialogue: Media Studios, no 24, pp. 132-154.

6. Pechonchik, T. (2016), «Why the language of hostility appears in the media?», available at: URL: http://www.cje.org.ua/ua/blog/chomu-mova-vorozhnechi-zyavlyayetsya-uzmi (accessed 3 November 2019).

7. Pikalyuk, R. (2018), «The language of hostility and the improvement of the standard of domestic media activity», in Virtos, I., Shenderovsky, I. (Ed.), Human Rights and 
Mass Media in Ukraine: Collection of lecture notes, Institute of Journalism, KNU them. T. Shevchenko, Kyiv, p. 135-147.

8. Savonchak, V. (2018), "The language of hostility in the media: a discussion of concepts", Visnyk Kharkivskoho Nationalnoho Universytetu im. V. N. Karazina. Serija Philologija [Visnyk of the Karazin Kharkiv National University. Series Philology], issue 79, pp. $76-81$.

9. Temchur, K. (2019), "Conflict discourse of the Ukrainian media during the aggression of Russia in the Sea of Azov", Visnyk Kharkivskoji Derzhavnoji Academiji Kultury [Visnyk of the Kharkiv State Academy of Culture], issue 54, pp. 108-116.

10. Virta, A., Shenderovsky, S. (Ed.) (2018), "Human Rights and Mass Media in Ukraine", Collection of Lecture Notes, Institute of Journalism of KNU T. Shevchenko, Kyiv, 260 p.

\title{
RELIGIOUS ISSUES IN THE INTERNET MEDIA OF LVIV REGION: CONCEPTUAL AND CONTENT COMPONENT
}

\author{
Oksana Hotsur \\ Ivan Franko National University of Lviv, \\ Generala Chuprynky Str. 49, 79044, Lviv, Ukraine \\ e-mail: o hotsur@ukr.net \\ https://orcid.org/0000-0002-6589-0011
}

The article analyzes materials on religious issues of Lviv region's online media. On the basis of content analysis of texts of such well-known regional online publications as "ZIK", "Zaxid. NET", "Look.Info", the conceptual accents in the coverage of religious issues are distinguished. Also, a negative semantic and semantic load of materials on religious issues is revealed.

It is noticed that functioning of such words and combinations of words in journalistic materials it is related to the important social and political processes and transformations in Ukraine is Russian-Ukrainian war and by the process of receipt by Orthodox Church of Ukraine of avtokefalii, handing of tomosu. The ponderable stake of texts in relation to kindling of religious enmity and intolerance is made by materials which contrast Ukrainian Orthodox Church of Moscow Patriarchy and Orthodox Church textual and semantically.

Publications on religious issues include such concepts with a negative meaning as Russian priests, Kremlin priests, indecisive Moscow believers, priests with shoulder straps, Putin's church «nuclear weapons».

On the basis of the analysed texts myths which arise up as a result of the use journalists in texts on religious problematiku of language of enmity are selected.

The hypothesis put forward in the study is that the hostility in journalistic materials of online information resources emerges as a consequence of reactions to events related to the religious life of Lviv and Ukraine, which has been confirmed.

On the one hand, journalists, using a language of enmity, emphasize expression in the coverage of problems, which, of course, can easily turn into aggression and religious intolerance in the reader's perception. This language is becoming a source of myth in the Ukrainian information space.

Key words: journalistic material, concept, publication, religious issues, internet media, The Orthodox Church of Ukraine, Ukrainian Orthodox Church of the Moscow Patriarchate. 